\title{
OUTLOOK ON BASIC EDUCATION QUALITY IMPROVEMENT
}

\author{
Burhanuddin Tola \\ Graduate School, Universitas Negeri Jakarta, Indonesia \\ burhanuddin.tola@gmail.com
}

\begin{abstract}
This study aims to explore an outlook of future quality basic education by deploying reference analysis varied sorts of resources. The analysis was conducted by analyzing current condition of improvement and enhancement of the learning access and opportunities of all primary school-aged children who reach Minimum Participation Rate (MPR) of $100 \%$ by 2015. This involved less economically developed, people living in remote, border and isolated areas and districts. Current and future analysis suggests the quality education lies not merely on achieving the MPR indicators of $100 \%$ along with the reduction of the percentage of students' learning period and the number of dropouts and retakes, but also on analyzing the periodical competence benchmark on the literacy achievement of Indonesian children. The achievement is greatly influenced by economic growth illustrated in Gross National Income (GNI) and Gross Domestic Product (GDP). This study found that future basic education quality significantly affect the economic growth of Indonesia.
\end{abstract}

Keywords: outlook of basic education, periodical competence benchmark, literacy achievement, GNI/GDP.

The vast development of science, technology and information in the globalization era taking place throughout all life sectors have brought positive and negative impacts to individuals and their social life. The Act No. 20, 2003 about National Education System stipulates that Indonesian children aged 7-15 should grow with norms and social values in order to shape the quality and competitiveness of Indonesian society. By this, the educational process utilizes the resources from and for the society. It is important that education enable to predict or look out the needs for simultaneous development of science, technology, social, economy, politics and citizenship with a view to maintaining social values and norms. Developing basic education is imperative as its design integrate all aspects of everyday practices. In this sense education serves as a means of developing human resources and positions them as "subject" of science, technology and information in this globalization eras (Sa’ud, U.S., and Mulyana, 2007; Suryadi, A., 2011).

Improving quality of future implementation of basic education requires several viewpoints, namely (1) the ideas of future basic education, (2) the factors influencing the learners, (3) the content of basic education, (4) the geographical condition of Indonesia, and (5) the diversity of Indonesian's cultures. However, prior to discuss these viewpoints, it is important to note what stems the implementation. The International Commission on Education for the Twenty-First Century which is founded by UNESCO and, chaired by Jacques Delors. The Commission reported its findings entitled Learning: The Treasure Within (1996) that focused its program on the sort of education required for future society. The Commission recommends that the future basic education has been one consideration to promote basic education quality in Indonesia (Sa’ud, U.S., and Mulyana S., 2007) as it becomes. 
The Twenty-First Century of Education Commission notices that future basic education is a the "passport" to life (Sa'ud, U.S., and Mulyana S., 2007). Basic education for children has been under concept of an early education for all children (formal or non-formal) that principally begins at the age of 3 (three) to at least 1215. Basic education as individual passport is highly recommended for life skills of learners to make choices in taking part in collective community development in the future and learning community throughout times (Delors, 1996).In this sense, this passport allows them to engage themselves both in local and global societies. The concept of basic education also closely relates to equal rights for appropriate and quality education as it is associated with human rights which are in compliance with Beijing Declaration. This makes, as argued by Sa'ud, U.S., Mulyana S. (2007), basic education becomes universal and specific.This universality stems from the World's Education on Education for Chapter 1 Act (1), which stated "every child, teenager, adult will benefit from opportunities to obtain education designed for meeting basic learning needs. These benefits includes basic learning abilities (e.g. literacy competence, oral expression, computing, and problem solving) and learning contents (e.g. knowledge, skill, values and attitude)”. Sa'ud, U.S., Mulyana S. (2007) perceives this not only as alignment to the life long education slogan but also as requirements for the learners to survive, enhance competence thoroughly, live and work in dignity, participate totally in development, improve quality life, make wellinformed decision and learn continuously.

In Indonesia the implementation of the basic education is realized through nine-year compulsory education program has been the implementation of basic education for all children aged 6-15. This program was initially implemented in 1994/1995 school year and re-promoted by President Susilo Bambang Yudhoyono. However, although Indonesia's compulsory education refers to universal education which widely opens learning opportunities for children, this program does not address the one applied in developed countries owing to following characteristics: (1) it merely forces learners to attend school; (2) it the program is governed by rules of schooling; (3) as the law does not stipulate any sanction nor reward for parents to have their children attend schools nor absent; (4) it imposes sanction for parents having left their children unschooled. Instead, Indonesia's compulsory education refers to a universal education which widely opens learning opportunities by having parents aspire to education for school-aged children. In other words, these attenuates the roles of: (1) persuasive approach; (2) parents' and learners' in education as the program merely focuses on for having had well-provided facilities; (3) unnecessarily specific laws applied in the schooling regulation; (4) macro indicators, such as the escalation of basic education participation rate; and (5) the equalityty and improvement of competence quality on reading, mathematical and science literacy at national and international scale.

The Trend International Mathematical Science Study (TIMSS), Program International Reading Literacy Study (PIRLS) and Program International Student Assessment (PISA), claimed that students' learning achievement enables to distinguish productivity of a country, rather than annual schooling rate or entrants' rate. A survey conducted by PISA indicates that a greater the difference in education has lied between developing countries and OECD countries when one does not only consider about level of the education access but also students' learning achievement (OECD, 2004; Wobmann, L., 2001). 
It is recommended that a state investigate the reason for having the absence of quality schools so that it will encourage the researcher to conduct a study with a view to investigating the best ways to improve the weakness. This is due to their belief in education paradigm, "building nation means building schools". Soedijarto, 2012 pointed out that "history has recorded that the success of nation state in building the nation, such as the United State of America, Germany, Great Britain, and Japan among other is because they held a paradigm "build nation build school”. In order to achieve this, education in developed countries is designed to adopt the principle of having schools as the center of culturalization.

In alignment with nation-state building, Shonkoff and Phillips (2000) argue that the process starts from the golden age of early childhood development. This age is so precious as it determines children's ability to perceive the facts as they function as stimulants for their personality, psychomotor, cognitive and social developments. Due to this, the pre-birth, after-birth until growth periods reaching age 15/17 have been the most determined to shape the future of the nation. Therefore, research foundations in the world i.e. World Bank, UNESCO, UNICEF, OECD, IEA, and other foundations have consistently conducted in-depth studies to investigate how human beings undergo their growth development from early childhood in order to improve the education quality for the early aged and primary school aged children in learning process and achievement.

The World Bank has placed an investment by allowing the education outcomes to be the overall international educational objectives. Unlike Shonkoff and Phillips (2000) who perceive childhood development as significant factors in basic education, Hanushek, E. and Ludger Wobman (1994, 2007) argues that not only does education quality emphasize on the access but also affects economic growth of one country. Well-known researches in the world have employed data on the relationship between economic growth and learner's competence as part of the issue on education. Findings reveal that the as the literacy competence to which the population of learner belongs has a significant and positive relation is closely related with people's income, income distribution and economic growth. However, Robert J. Barro (2001) notes that there are four doubts regarding this issues in relation to the different policy and its implementation between developed and developing countries. Firstly, it lies on the different way they develop education. Secondly, although both developed and developing countries have enhanced the opportunities and role of schooling, yet they do not impact the economic growth. Thirdly, the lessfunctioned system attenuates the effectiveness of educational program. Fourthly, many learning strategy approaches have been left ineffective to generate the quality of graduates.

Based on this research focuses on addressing the following questions: (1) to what extend does the enhancement of education access and learning opportunities increase Pure Participation Rate (PPR) of all primary school aged children in less economical, border, remote, and isolated areas? (2) How does the efficiency and effectiveness of education resource management improve the completion rate of basic education? (3) How is the delayed completion rate of basic education level attenuated the improvement of efficiency and effectiveness of education resource management? (4) How does the improvement of quality and relevance in basic education reduce the rates of the retake and dropout? (5) How is the learners' 
competence on reading, mathematical, and science literacy improved the international benchmarking study and economic growth?

\section{METHOD}

This is a qualitative approach with using literature study which focuses on several key element issues: participation rate, completion rate, delayed completion rate, retake and dropout rates, and relationship between learners' competence, i.e. reading literacy, mathematical literacy, science literacy related to international benchmarking and economic growth.

\section{RESULTS AND DISCUSIONS}

\section{Analysis of Recent Basic Education Condition}

The nine-year compulsory education program is a government program to equip learners with basic skill and knowledge. This program aims to enable learners to pursue higher level of education, survive in society, make choices in life and utilize hi-tech products, interact and compete with individuals and people across nations.

To ensure completion rate of basic education, the Indonesian Government has proclaimed a nine-year compulsory education program that consists of six-year primary school program (children aged 7 -12) and three-year junior high school program (children age 13-15) periods. This shows that Indonesia has set up its target of Millenium Development Goal (MDG) in basic education further than that of international standard. This target is to ensure that all children of all genders are able to complete the six-year primary school program by 2015. This is not only in line with that of the nine-year compulsory education program but also show the trend of participation rate in basic education which is reflected on Rough Participation Rate (RPR) indicator 99 percent for junior high school (JHS) level by 2015. The success of the program depends on the improvement of basic education quality in a number of provinces having below standard of reading, mathematical and science literacy based on the international standard of TIMSS, PIRLS and PISA.

\subsection{Participation Rate}

As for participation rate of primary school level, survey on national socioeconomy indicates that the PPR of primary school (PS) for children age 7-12 has significantly increased from $88.7 \%$ to $92-93 \%$ from 1992 for the past three years. This PPR is subjected to the escalation trend of PPR (maximum 100\%). It is projected that the PPR of junior high school will reach 99\% in 2015. However, this projection does not guarantee the overall quality of achievement, as a disparity in education quality takes place among education institutions in all provinces.

These trend and projection also show that PPR is a different measurement device from RPR. The Ministry of Education and Culture (MONE) reported that the RPR of primary schools shows that they reached 112 percent in 2012 which is significantly higher than MPR's prediction (94 percent). This signifies that there is a great number of learners below seven years old and above twelve years old 
attending primary schools. There are two possibilities why the twelve years old children still participate in primary school. Firstly, they might have enrolled in the primary school at the age of seven, and above as 42.2 percent of children entered the first year of PE at the age of eight and above in 2000/2001 school year. Secondly, few children failed to complete their schooling at the age of twelve and above.

The high disparity between PPR and RPR of PS remains as according to 2002 survey on national socio-economy demonstrates there is merely slight difference is a fact that this occurs in all groups of society with slight significant differences between urban and rural areas, male and female learners, and less and better economically developed society which is measured on the basis of family's expenditure consumption. However, the difference lies on the different number of PPR which varies amongst provinces (some of them are below 90 percent). This condition shows that better education access to JHS greatly improves the implementation of the nine-year compulsory education program.

Similar condition also happens in JHS also remain. However, unlike PS, there has been a existing the difference lies on the participation of education for JHS between rural and urban areas and the less and better economic families. As for

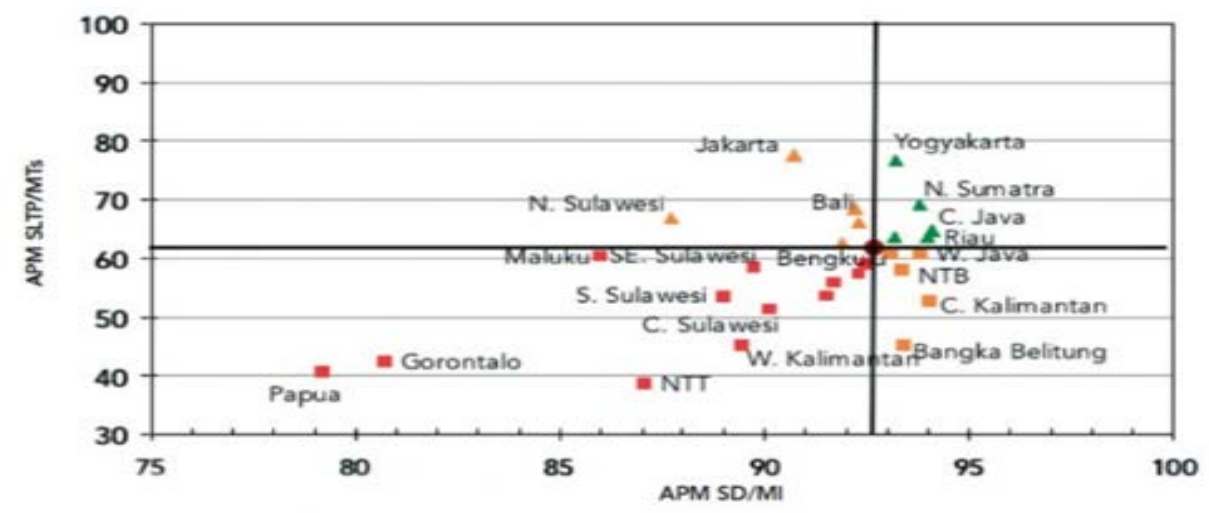

Figure 1. PPR PS and JHS, 2002. Source: Susenas, 2002

gender, the disparity remains the least evident. Contrast PPR disparity also takes place amongst provinces that shows below 60 percent (Figure 1) which is seemingly to appear as a potential problem.

\subsection{Completion rate of primary school learners}

The proportion of learners successfully attending year 1 to year 5 of primary school increased from 74.7 percent in 1991 to 82.2 percent in 2002. Whereas the completion rate of learner - those who continue to complete their nine-year compulsory education program - can be seen in the cycle of primary school learner. This indicates the success in the implementation of nine-year compulsory education program and improvement of basic education completion rate in the past eleven years.

\subsection{Delayed completion rate of primary school learners}

Delayed completion rate of primary school learners remained high in the past nine years. Data shows that 67.9 percent of PS learners in 1982/1983 school year 
failed to complete their nine-year compulsory education program. This phenomenon recurred in 1993/1994 to 2001/2002 cycles in which 53.2 percent of learners failed to complete their basic education within a required period of study. This results from (1) the retakes who take longer period of time to complete their primary school, (2) the dropouts who withdraw from attending alternative education institutions in order to complete their basic education, and (3) the graduates of primary education level who fail to continue their education to SLTP/MTs or school of the same level that offers non-formal education. This leads to the escalation of the number of illiterate learners.

\subsection{Retake and Dropout rates}

The improvement of completion rate of basic education in terms of the above cases above (in 1982/1983 and 1993/1994) are due to the following factors: decline of retake rate, decline of dropout rate, increase rate of learners continuing their first secondary education, and combination of these three. These factors are promoted by the positive impact of the presence of nine-year compulsory education program.

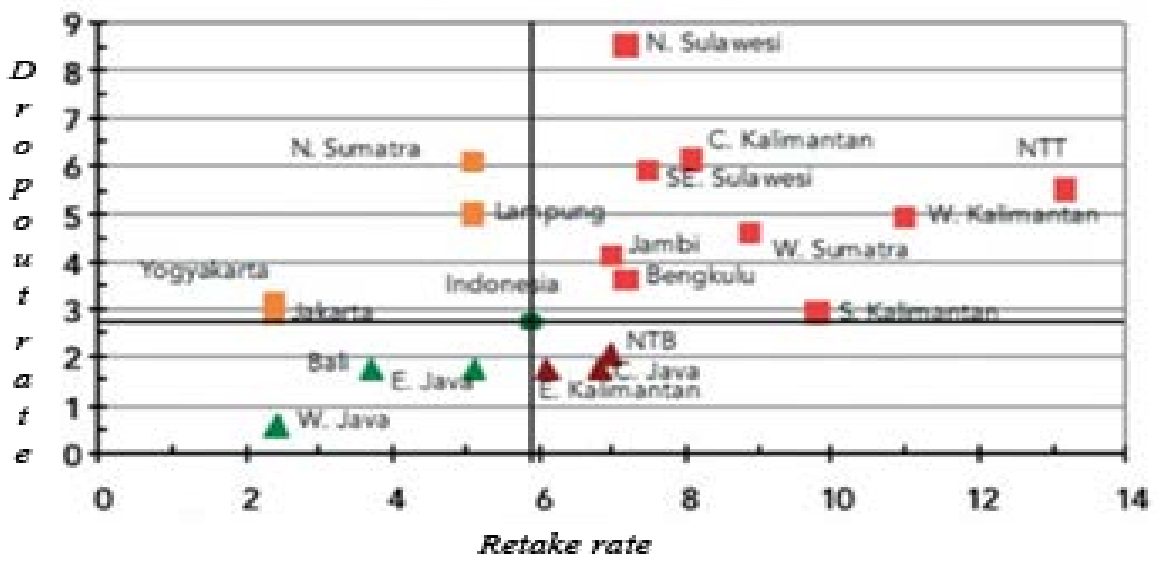

Figure 2. Retake rate and dropout rate of PS and JHS, 2002. Source: Susenas, 2002

However, these rates are subjected to further enhancement considering the high retake and dropout rates of primary school learners and the low rate of junior high school entrants. These rates are influenced by cultural values and common practice in Indonesian society, lack of understanding on the importance of education, effete law enforcement on education that is supposed to impose the society to be part of its process for which further analysis is required.

On the other hand, dropout rates of PS and JHS were 2.6 and 4.4 percents in 2000/2001 whilst retake rates were 5.9 and 0.3 percents respectively. Serious attention should be paid on the high rate of the retakes in PS in particular as it affects school completion rate and dropout rate (Figure 5). Alternative education institutions are supposed to function effectively and affordable for dropout school children aged 7-15 in both PS and JHS. Literacy rate should reach close to $100 \%$ at the age of 1524 or above 15.

As for the completion rate of the retakes and dropouts, The low completion rate of basic education nationwide is evident that the retake and dropout rates the rate remains high in the provinces or districts. The retake rate reaches 2.7 to 13.5 percent whilst the dropout is below $1.0 \%$ to over $8 \%$. The completion rate of the 
fifth-year learners in 1991-2002 increased from 74.7-82.2 percents despite existing differences between the societies occupying rural and urban areas and those of the less and better economically developed.

\subsection{Literacy Competence, Benchmarking and Economic Growth}

Findings of study show that the relationship between education quality and economic growth is relatively equal in OECD and non-OECD countries. The influence of education quality towards economic growth between these two groups is statistically less significant. In addition, findings of former qualitative study reveal that it comes to be equal when openness and institution quality are positioned as controlling variables. The factor that heavily influence the education quality lie on the applies to a group of low-income countries rather than high-income if samples of study are classified into countries belonging to a group of above and below Gross Domestic Product (GDP) Median per capita of the OECD and non-OECD countries. This proves that education quality mostly affects low-income rather than highincome countries (De Gregorio, 2002). This can be seen from Figure 2 which shows demonstrates that test score during schooling period becomes significant factor towards the economic growth. Compared to the other developing countries, Indonesia succeeds in promoting the relationship between learning outcomes during schooling period to be in line with the economic growth. Figure 3 shows that the test score affects economic growth on both high-income and low-income countries. Indonesia, among countries which belongs to the group of developing countries, successfully improve its education quality despite its low GNI/GDP per capita. Indeed, high disparities in education quality remain evident in all over provinces, districts, or education institutions. By this, schooling period and competence achievement should be positioned as the indicator of progress and improvement by means of standardized learning which is in line with contextual teaching learning.

\section{Analysis Of Future Condition Of Basic Education}

This sub section focuses on the analysis of future condition based on the current condition and the perspective of basic education perspective or outlook by considering what foregrounds them, the objective, target and benefit. As previously

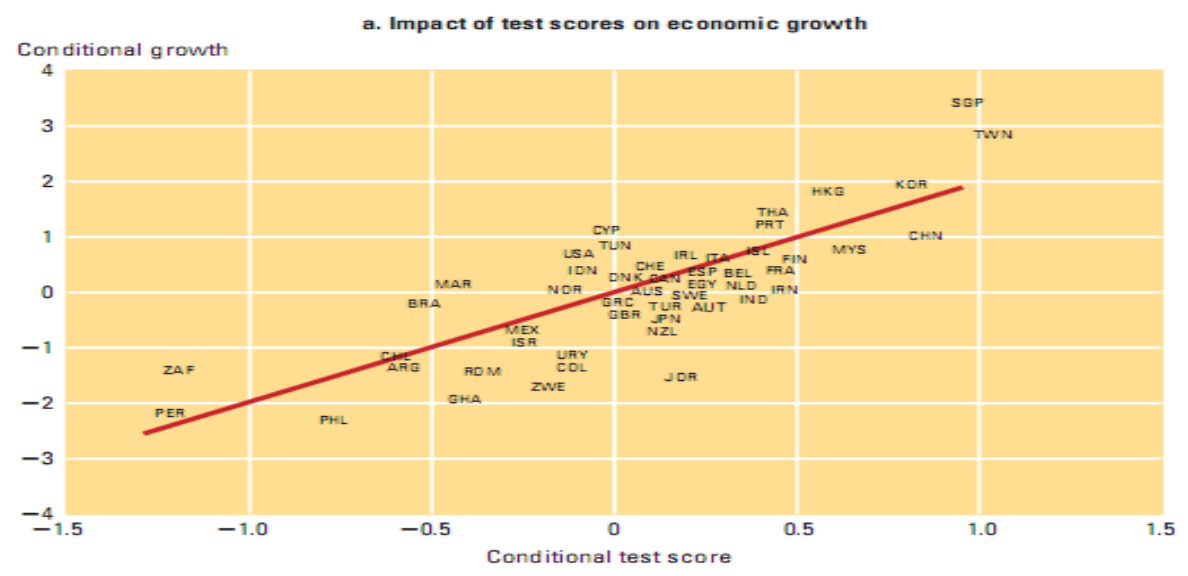

Figure 3. Test score during schooling period has a significant influence towards economic growth. 
discussed, the crucial points pertinent to the future perspective of basic education are (1) an increase of participation rate, (2) an increase of completion rate, (3) a reduction of delayed completion rate, (4) a reduction of retake and dropout rates, (5) an increase of global competition in reading, mathematical and science literacy that will significantly give impact to economic growth.

The PPR increases. As having been projected, in 2015, the PPR of PS will reach the percentage above $100 \%$ in respective districts (see Figure 1), and reach $100 \%$ for the national level. However, it remains varied in some parts of districts due

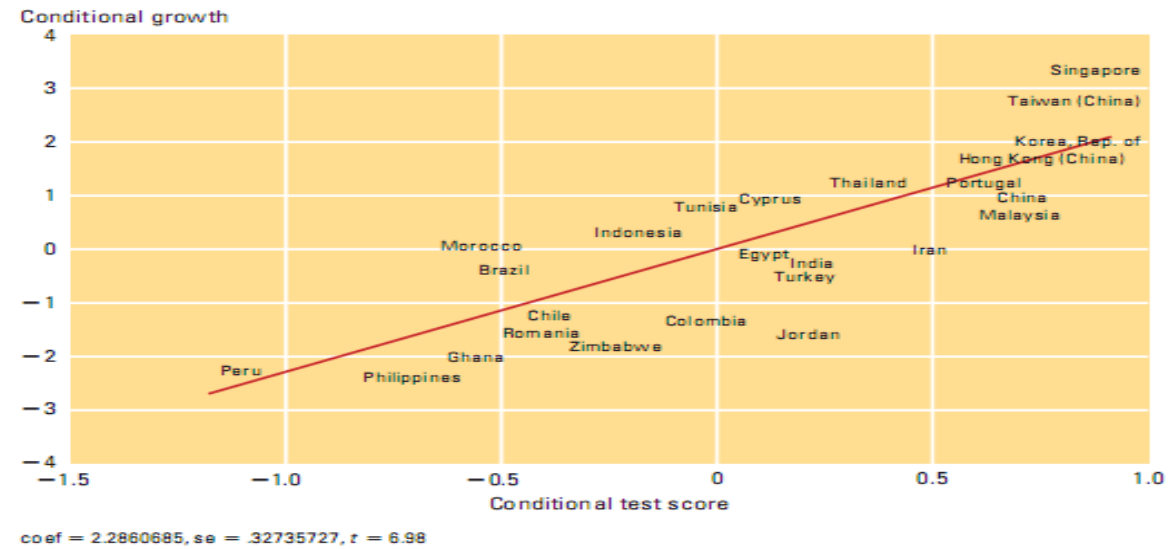

Figure 4. Test score affects economic growth on both high-income and low-income countries.

to differences found in education quality service and economic growth. The 2002 survey on national socio-economy, found that Indonesia successfully achieved high percentage in PPR for the primary level of education PS. This opened a wider education access for learner to continue their studies to junior high school level JHS which also resulted from the nine-year compulsory education program. Despite this wider open access , the PPR disparity in 20 percent of the least economic group of society (Quartile 1) reaches the percentage of 49.9 compared to 72.3 percent of the better economic group.

The RPR of JHS also varies among rural (69.7 percent) and urban (93.5 percent) areas and the less (64.8 percent) and better (94.6 percent) economic groups. This also occurs among provinces which have PPR below 60 percent, that are: Gorontalo, East Nusa Tengara (NTT), West Kalimantan, South Sulawesi, Central Sulawesi, Central Kalimantan, South Kalimantan, Southeast Sulawesi, and West Nusa Tenggara (NTB) exemplify this including Papua which gained 40.5 percent of PPR according to 2001 survey on national socio-economy. With a view to increasing the PPR of JHS, a program approaching individual and groups of society is required to design on the assumption that the absence of differences among rural and urban areas, between genders and family's expenditure consumption-based groups of society must exist to utilize the service and opportunity in education, improve learning achievement, enable individuals and families to obtain learning opportunity, and enroll in public and private schools.

There was a significant increase in the completion rate of year five of primary school students from 74.7 percent in 1991 to 82.2 percent in 2002. It will have been rocketing up to 90 percent in 2015 prediction. This 8 percent increase ranging within ten-year period of time is evidently crucial to be investigated. Some drawbacks encountered possibly relate to competence development which is not adjacent with 
the learners' maturity. To meet the objective to increase the completion rate to 100 percent requires (1) a policy to ensure learners to pass the grade (definite promotion), (2) a diagnose on learners' weakness, (3) remedial courses, (4) learning facility (5) scoring system, and (6) teacher and educator quality.

Nevertheless, the completion rate of nine-year education failed to meet its target as evidenced by the great number of learners having delayed completion. There was 67.9 percent of the total year-1 learners of PS in 1982/1983 failed to accomplish their nine-year basic education program. This phenomenon re-occurred in 1993/1994 and 2001/2002 as merely the rate reached 53.2 percent. In order to reduce the number, several factors are needed to improve, such as school-based management policy, (2) diagnose on learners' weakness, (3) consistent remedial courses be consistently carried out in integration, (4) learning facility be wellupgraded (5) better scoring system be well-organized in integration, and (6) teacher and educator quality be improved in line with learners' growth.

As previously mentioned, data shows that the national retake and dropout rates of provinces or districts are high, as the retake rate lies on the range of 2.7 to 13.5 percent whereas the dropout rate covers below 1.0 to 8 percent in addition to the low rate of PS learners continuing to JHS. The following is the factors that influence the escalation of the retake and dropout rates: (1) cultural values and common practices in the society; (2) lack of understanding on the importance of education; (3) effete law enforcement on education that is supposed to impose the society to be part of its process for which further analysis is required.

Form all the factors discussed, this literacy competence has been interpreted as education quality. A greater influence of education quality applies to a group of low-income countries rather than high-income if samples of study are classified into countries belonging to a group of above or below Gross National Income (GNI) Mean Score and Gross Domestic Product (GDP) per capita taken in from the World of 2006. The score on literacy competence during schooling period holds a significant role, especially in developing countries rather than developed countries, towards in relation with their economic growth. Indonesian successfully promote the learning outcomes of the learners during schooling period to be in line with economic growth.

The relationship between GNI/GDP and the score of reading, mathematical and science literacy as well as its progress is illustrated in the following diagram. This demonstrates a relationship between GNI/GNP and learners' learning achievement in reading, mathematical, and science literacy. If Indonesia's GNI/GDP increases continuously, the Indonesian children's learning achievement in literacy will tend to increase significantly. This will enable them to compete with their fellows in other OECD countries and non-OECD developed countries. Analysis of the Indonesian children's literacy condition in the future and the probability variables that promotes improvement will be thoroughly discussed below. The discussion is organized by focusing on the relationship between GDP and mathematical, reading, science literacy.

\section{a. Relationship between GNI/GDP and Mathematical Literacy Score}

In general, there has been a fluctuation in the mean of mathematical literacy score taking place in OECD and non-OECD countries during three periods of study (2000, 2003, and 2006). Although Indonesia is positioned as a non-OECD country 
with low GNI/GDP, Indonesian children have successfully obtained higher learning achievement than that of other high GNI/GDP countries (see Table 1). This can be seen from the mean of mathematical literacy score of Indonesian children which is higher than those of non-OECD countries despite having low GNI. In other words, there has been a gradual increase in the mathematical literacy score of Indonesian children every period of study (see Table 1).

Table 1. GDP of non-OECD Countries and Mathematical Literacy Score

\begin{tabular}{clcccc}
\hline No. & Country & GNI/GDP & PISA 2000 & PISA 2003 & PISA 2006 \\
\hline 1. & Liechtenstein & 65,000 & 519 & 538 & 526 \\
2. & Latvia & 8,100 & 466 & 485 & 488 \\
3. & Russian F & $5,780 / 8,030$ & 480 & 469 & 477 \\
4. & Argentina & 5,150 & 394 & - & 387 \\
5. & Brazil & 4,730 & 338 & 361 & 372 \\
6. & Thailand & $2,990 / 3,420$ & 435 & 419 & 420 \\
7. & Tunisia & 2,970 & - & 360 & 367 \\
8. & Columbia & 2,740 & - & - & 372 \\
9. & Jordan & $-/ 2,480$ & - & - & 395 \\
10. & Indonesia & $\mathbf{1 , 4 2 0 / 3 6 9}$ & $\mathbf{3 6 9}$ & $\mathbf{3 6 2}$ & $\mathbf{3 9 3}$ \\
11. & Kyrgyzstan & 490 & - & - & 316 \\
\hline
\end{tabular}

There is a varied way to see the trend of mathematical literacy score in OECD and non-OECD countries. The table above shows that in 2000, 2003, and 2006, the trend of mathematical literacy score in OECD and non-OECD countries it is noted that both groups have had a significant increase significantly in mathematical literacy within 2000, 2003, and 2006. The system of measuring the quality of learning influences this trend. Therefore, the score gained by every group of countries developed, developing, and/or under developed - is significantly influenced by the system of learning quality applied. Thus, it is projected that, it is argued that mathematical literacy of Indonesian children will be higher continuously if supported by high GNI/GDP and better learning condition.

\section{b. Relatioship between GNI/GDP and Reading Literacy Score}

In general, there has been a fluctuation in the mean mathematical literacy score taking place in OECD and non-OECD countries during three periods of study. The mean reading literacy score decreased in all countries, including OECD countries belonging to PISA with GNI of 5400-76040. As for Indonesian children, they successfully obtained higher learning achievement than those of countries with high GNI/GDP (see Table 2).

Table 2. GNI/GDP of non-OECD Countries Reading Literacy Score

\begin{tabular}{clcccc}
\hline No. & \multicolumn{1}{c}{ Country } & GNI/GDP & PISA 2000 & PISA 2003 & PISA 2006 \\
\hline 1. & Qatar & & - & - & 337 \\
2. & Hong Kong, China & $28,460 / 29,350$ & 529 & 514 & 539 \\
3. & Russian Federation & $5,780 / 8,030$ & 463 & 443 & 442 \\
4. & Argentina & 5,150 & 424 & - & 381 \\
5. & Romania & $4,850 / 6,340$ & 432 & - & 400 \\
6. & Brazil & 4,730 & 401 & 408 & 396 \\
7. & Montenegro & 3,860 & - & - & 398 \\
8. & Thailand & $2,990 / 3,420$ & 433 & 422 & 420 \\
9. & Tunisia & 2,970 & - & 377 & 382 \\
10. & Columbia & 2,740 & - & - & 388 \\
11. & Azerbaijan & 1,850 & - & - & 357 \\
12. & Indonesia & $\mathbf{1 , 4 2 0 / 1 , 5 9 0}$ & $\mathbf{3 7 3}$ & $\mathbf{3 8 3}$ & $\mathbf{3 9 5}$ \\
13. & Kyrgyzstan & 490 & - & - & 291 \\
\hline
\end{tabular}


The mean reading literacy score Indonesian children reach is higher than that of non-OECD countries despite having low GNI/GDP (see Table 2). Therefore, the score gained by every group of countries - developed, developing, and/or under developed - is significantly. Like in the case of mathematical literacy score, the system of learning quality also influences the reading literacy score. Thus, it is argued that the reading literacy of Indonesian children will be higher continuously if supported by high GNI/GDP, better learning condition. It will have reached above the average score of international study in three periods of study (12 years) on the assumption that there will be better and intervention in policy to provide wellfacilitated learning aids and a more effective function of the influenced learning variables promoting learning outcomes.

\section{c. Relationship between GNI/GDP and Science Literacy Score}

In general, there has been a flat in the mean of science literacy score taking place in OECD and non-OECD countries belonging to PISA. The mean of reading literacy score remained relatively flat in OECD countries ranging from GNI 5400 up to 76040 during three periods in 2000, 2003, and 2006. Nevertheless, belonging to non-OECD country with low GNI/GDP, However, Indonesian children successfully obtained higher learning achievement than that of other high GNI/GDP countries (see Table 3), as the mean of science literacy score Indonesian children reach is higher than that of non-OECD countries despite having low GNI/GDP. On the other In other words, there has not been a significant increase in the science literacy score of Indonesian children every period of study (see Table 3).

Table 3. GNI-GDP of non-OECD Countries and Science Literacy Score

\begin{tabular}{clcccc}
\hline No. & \multicolumn{1}{c}{ Country } & GNI/GDP & PISA 2000 & PISA 2003 & PISA 2006 \\
\hline 1. & Liechtenstein & 65,000 & 482 & 527 & 523 \\
2. & Latvia & 8,100 & 464 & 491 & 492 \\
3. & Russian F & $5,780 / 8,030$ & 462 & 490 & 481 \\
4. & Brazil & 4,730 & 378 & 394 & 393 \\
5. & Tunisia & 2,970 & - & 386 & 387 \\
6. & Columbia & 2,740 & - & - & 390 \\
7. & Azerbaizan & 1,850 & - & - & 386 \\
$\mathbf{8 .}$ & Indonesia & $\mathbf{1 , 4 2 0 / 1 , 5 9 0}$ & $\mathbf{3 9 5}$ & $\mathbf{3 9 7}$ & $\mathbf{3 9 5}$ \\
9. & Kyrgyzstan & 490 & - & - & 326 \\
\hline
\end{tabular}

The trend of mean science literacy score in either OECD or non-OECD countries remained relatively flat. With reference to the statistically, there was a significant increase in science literacy score in OECD and non-OECD countries. Therefore, the score gained by every group of countries- developed, developing, and/or under developed is significantly influenced by the system of learning quality. Like the trend of mathematical and reading literacy score, I argue that the reading literacy of Indonesian children will increase continuously if supported by high GNI/GDP and better learning condition.

\section{d. Benchmark of Mathematical, Reading, and Science Literacy Competence}

Measuring learners' literacy competence of learners in countryies participating in PISA, relies on international benchmark designed by OECD. Benchmark of reading literacy constitutes five levels, whereas mathematical and science literacy respectively six levels for mathematical and science literacy ranging 
from basic to advance levels (Scheerens, J., 2000). The low competence of Indonesian learners in mathematical literacy is due to the lack of competence in algorithm, data interpretation, problem solving, and findings formulation.

Table 4. Description of Indonesian Learners' Mathematical Literacy at Each Level of Competence (Benchmark)

\begin{tabular}{ccc}
\hline Level of Competence & Score & Percentage (\%) \\
\hline Below level 1 & Below 357,77 & 35,3 \\
Level 1 & $357,77-420,07$ & 30,5 \\
Level 2 & $420,07-482,38$ & 20,4 \\
Level 3 & $482,38-544,68$ & 10,6 \\
Level 4 & $544,68-606,99$ & 2,8 \\
Level 5 & $606,99-669,30$ & 0,4 \\
Level 6 & above 669,30 & 0,0 \\
\hline
\end{tabular}

Table 5 illustrates the percentage of Indonesian learners of all levels with mostly (58.30\%) belong to basic level (level 1 and level 2). As for the higher level learners, the low percentage of their results of learners belonging to higher level results derives from the lack of understanding the idea of paragraphs, interpreting charts, comprehending relationship of facts and logical linguistic features, and identifying the main ideas of texts.

Table 5. Description of Indonesian Learners' Reading Literacy at Each Level of Competence (Benchmark)

\begin{tabular}{ccc}
\hline Level of Competence & Score & Percentage (\%) \\
\hline Below level 1 & Below 334,75 & 21,8 \\
Level 1 & $334,75-407,47$ & 36,5 \\
Level 2 & $407,47-480,18$ & 29,1 \\
Level 3 & $480,18-552,89$ & 11,1 \\
Level 4 & $552,89-625,61$ & 1,5 \\
Level 5 & above 625,61 & 0,1 \\
\hline
\end{tabular}

Table 6 illustrates the relatively high percentage (61.60) of Indonesian learners at basic level (level 1 and level 2). The low percentage of learners in science literacy competence derives from the lack of identifying scientific problems, employing scientific facts, understanding the life system, and understanding the utilization of scientific equipment.

Table 6. Description of Indonesian Learners' Science Literacy at Each Level of Competence (Benchmark)

\begin{tabular}{ccc}
\hline Level of Competence & Score & Percentage (\%) \\
\hline Below level 1 & Below 334,94 & 20,3 \\
Level 1 & $334,94-409,54$ & 41,3 \\
Level 2 & $409,54-484,14$ & 27,5 \\
Level 3 & $484,14-558,73$ & 9,5 \\
Level 4 & $558,73-633,33$ & 1,4 \\
Level 5 & 633,33-707,93 & - \\
Level 6 & above 707,93 & - \\
\hline
\end{tabular}

Since the mid 1960s, international agencies conducted numerous testing on literacy competence or recently called as international literacy competence based on the learner's performance, i.e. mathematical and science competence. Hanushek and Kimko (2000) investigated the education quality and found that statistically and economically its measurement promoted positive and significant effects of the 
economic growth in 1960-1990. They estimated that a country with deviation standard rate (equivalent to test-score of 47 of PISA Mathematics resembling the scale in Figure 3) is higher in performance test than performance test would result $1 \%$ higher than the annual growth rate.

A statistical model of the annual estimation of GNI/GDP growth per capita is deployed to measure the education quality, schooling years, initial income rate, and few other controlling variables, such as different specifications, growth of population, political measure, and economic openness. Hanushek and Kimko (2000) claimed that improvement of education quality in basic specification, initial income, and education quantity which allows the variation of GNI/GDP per capita among 31 countries can be explained by the model ranging from 33\% to $73 \%$. This improvement takes place in developed schools which position that the measurement involves overall literacy competence, home and other settings as the significant variables for growth analysis. The statistical overview of the test score on the significant influence of the actual GNI/GDP per capita in 1960-2000 positions the initial level of GNI/GDP per capita and schooling years as the controlled variables. The test-score measured a statistical overview on the significant influence of the actual GNI/GDP per capita in 1960-2000. Based on this, the higher test-score than deviation standard rate (measured on the overall levels of education learners in PISA's OECD countries) was associated with the average estimation of the annual growth rate of GNI/GDP per capita. This shows that the annual growth is $2 \%$ higher than that of during 40-year period in total. In this sense, the eeducation quality significantly relates to the economic growth. By this, the economic growth emphasizing on the framework of educational institution which promotes the economic openness for international trade and property security determines the learning resources. The economic growth emphasizes on the important framework of educational institution applied in the economic openness for international trade and property security. However, the education qualityy influences the economic growth which has been decreased to 1.26. Figures 5 and 6 show Indonesia's holding position in contrast to the schooling years and economic growth of other countries which have been in their low regression. This arguably indicates that schooling years has no significant influence towards the economic growth.

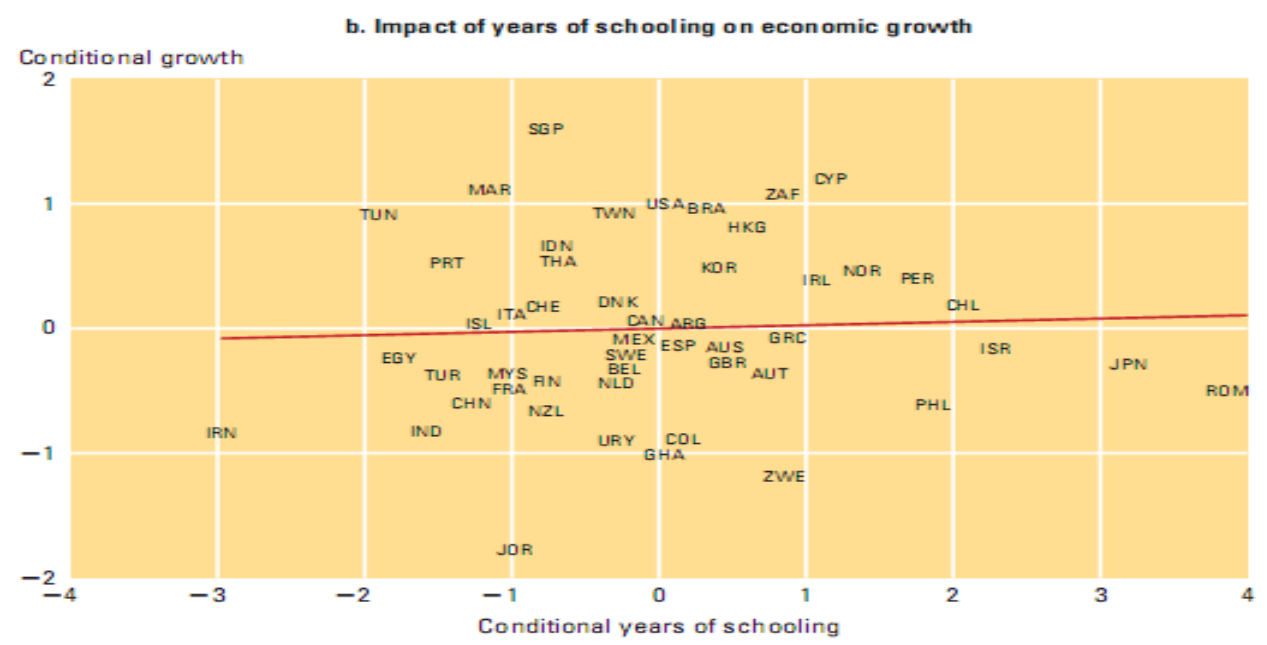


Figure 5. The Relationship between School Condition and Influence of Schooling Years towards Economic Growth

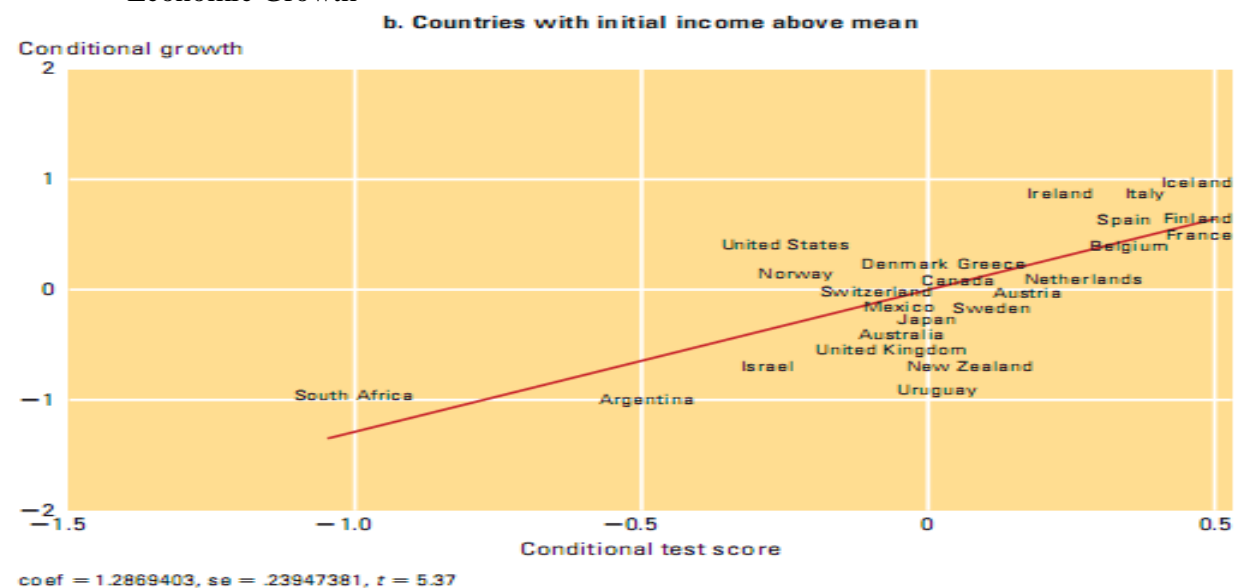

Figure 6. The Relationship between Test-score and The OECD Countries’ above Averaged GNP

The figure above illustrates the result of the test score which can be used for the analysis of the two sub periods, i.e. 1960-1980 and 1980-2000. The latter involves Asian crisis which occured in the late 1990s and other major economic barriers which revealed the influence of education quality towards the economic growth. The result of this test-score contribution can be seen as indicator of the positive influence towards the economic growth of these two periods (Coulombe S., 2000).

There have been two ways to predict future education quality. First, it can be seen through the change in school activities performed by learners that promote learning achievement, such as the overtime learning process. Although it is difficult to set out and carry out a timeline of improvement, it is recommended that the ddeviation standard of 0.5 be achieved within 20 to 30 years nationwide. Second, if the improvement of education quality succeeds, it will give an essential influence towards the economic growth by allowing learners to subsequently meet the completion rate and be part of workforce.

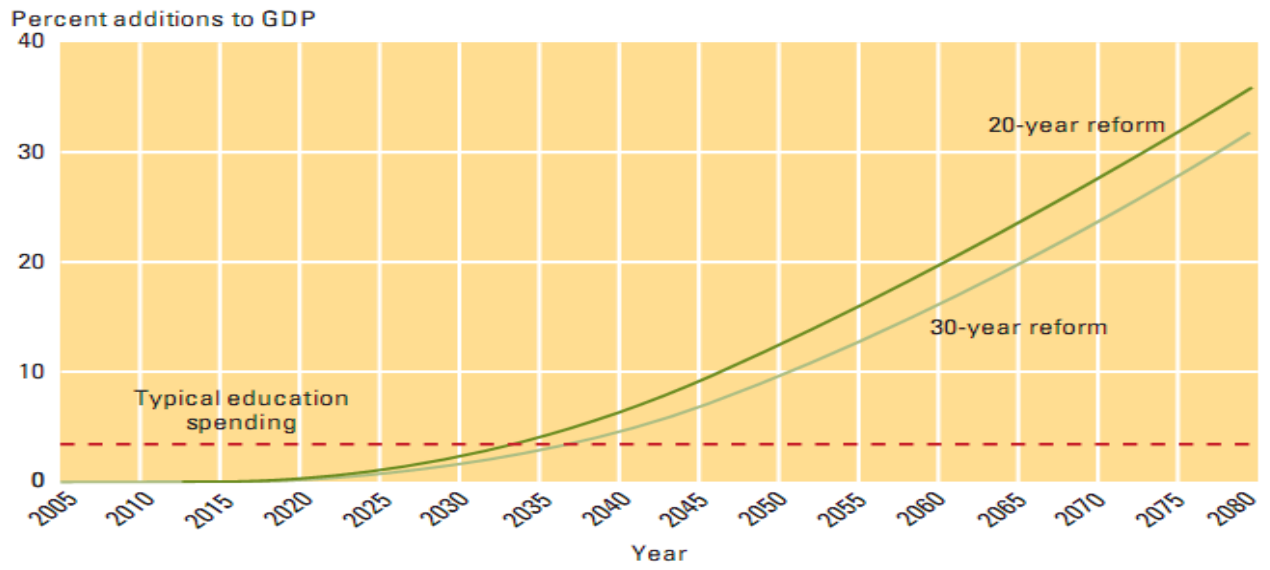

Figure 7. Significantly Improving GDP by means of Providing Knowledge about Improvement $(0.5$ Deviation Standard) 
The graph in Figure 7 shows indicates a significant influence in the policy improvement of education quality in relation to the economic growth within the range of 20 or 30 years period of time with 0.5 deviation standard of the learning outcomes in the completion of secondary level of education known as "influenced advancement in the knowledge of secondary-level”. In 2005 the World Bank proposed its 20-year policy beginning in 2005 in order to realize the education quality improvement. The policy is expected to produce 0.5 higher standard of the margin of achievement which shows the graduates' performance compared with the annual standard margin of 0.025 . This also essentially influence the economic growth by taking the employment age into account. This figure also points out the significance of GNI/GDP rate following the implementation of education quality improvement. In other words, the rate should excel other growth factors.

The education quality improvement has a crucial impact on the economic growth, even within the 20-30 years of planning. This ows to the fact that education quality will yield better graduates without delayed employment (Figure 7). With the absence of planning, education quality improvement remains absurd. The planning consequently yields GNI/GDP of 5\% higher by 2037. Figure 7 also illustrates that $3.5 \% \mathrm{GNI} / \mathrm{GDP}$ an aggressive expenditure on education is significantly high for one country to spend on the education quality improvement for primary and secondary levels. Thus, GNI/GDP of $5 \%$ refers to the considerable change which allows the economic growth to increase. This will cover the primary and secondary levels of education's expenditure. The presence of education quality improvement will yield actual GNI/GDP of 5\% higher by 2041. The increase of education quality is equal to the improvement period which closely correlates with its significant influence. By

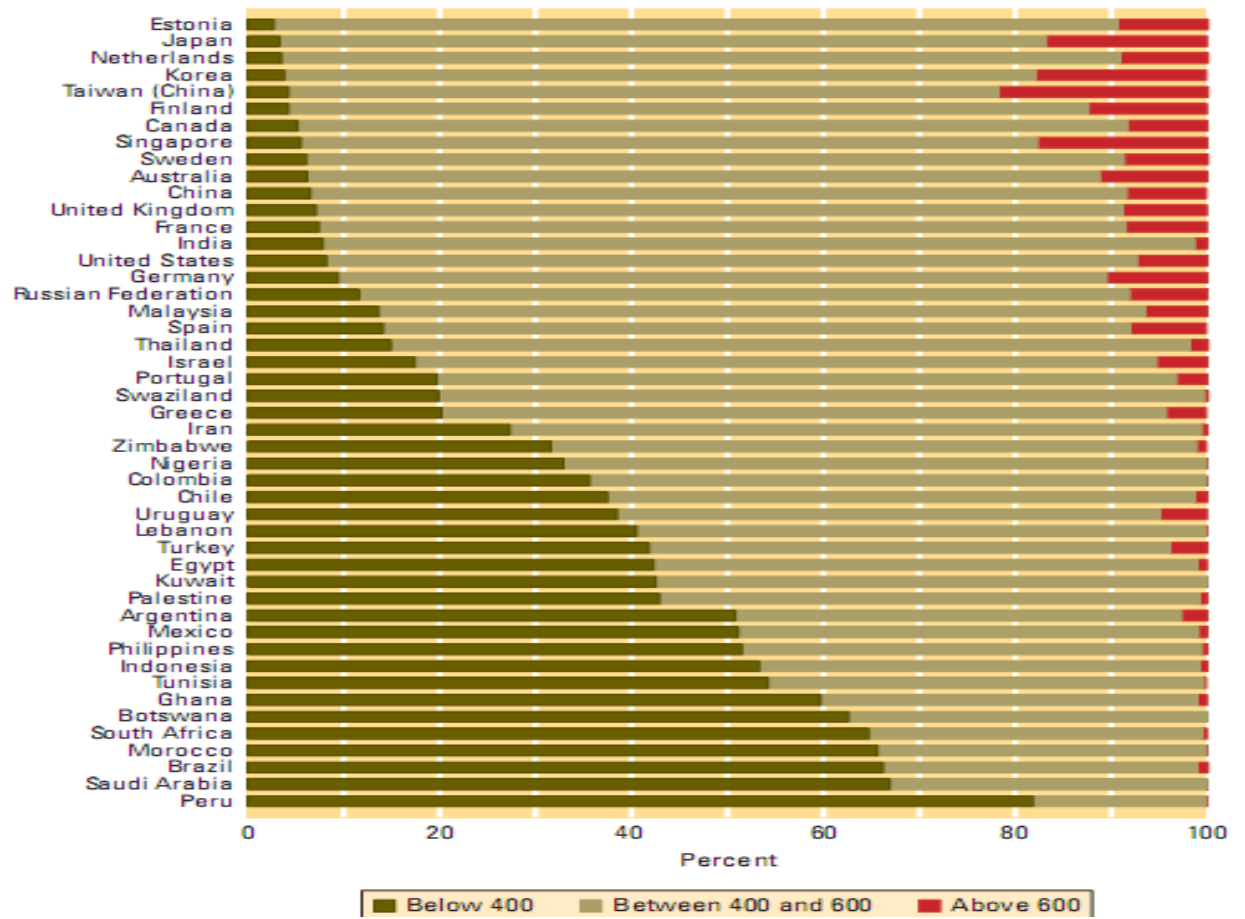

Figure 8. Distribution of Learners' Literacy Competence of Test-Score below 400, between 400-600, and above 600 in Selected Countries. (Resource: Hanushek and Wößmann, 2007) 
75-year projection, this 20-year improvement will produce an actual GNI/GDP of $36 \%$ higher.

How to overcome low education quality? As previously discussed, some schools ignore the learners' level of their literacy. Learners from developing countries who can complete 5 or even 9 year schooling period are falsely suggested that they be better-functioned in literacy competence. A recent report by the World Bank Independent Evaluation Group in (2006) stated that this institution had agreed to finance the extent program for schooling period (over 15 years) for primary level in developing countries.

Figure 8 illustrates the distribution of learners’ literacy competence in selected countries participating in the international study with the test-score ranging from 400 - 600 on the combined change scale. Similar measurement and range also apply on the growth analysis of these country. When comparing learners' achievement in basic education level of these country, the distribution exceeds 400 points on reading, mathematicc, and science literacy. Thisis figure also describes that the distribution goes much further than that of developed countries with above $60 \%$ of learners failed to accomplish the reading literacy. The selected countries participating in the international test has probably been become the samples for all other developing countries in the world.

Figure 9 illustrates the learner's performance in 4 (four) settings. This includes the presence of testing center and school autonomy which influences the teacher's salary having controlled a dozen backgrounds of learners', families, and school. School autonomy suggests that teacher's salary has a negative relation with the learners' performance in no testing-centered system and vice versa. On the contrary, the teacher's salary compensated from school autonomy has positive relation with the learner's performance in testing-centered system established by TIMSS and PISA (Bishop J.H., 1997; Galliani, S, 2002; Jurges, H., 2005). Similarly, there is a negative relation between external and autonomy testing.

The major problem existing in a school policy today is the lack of encouragement or motivation to improve the learners' performance as the center of appreciation by external party. With the absence of motivation, a study investigated that, the increase in teachers' salary proves inconsistently with the improvement of the learners' performance.

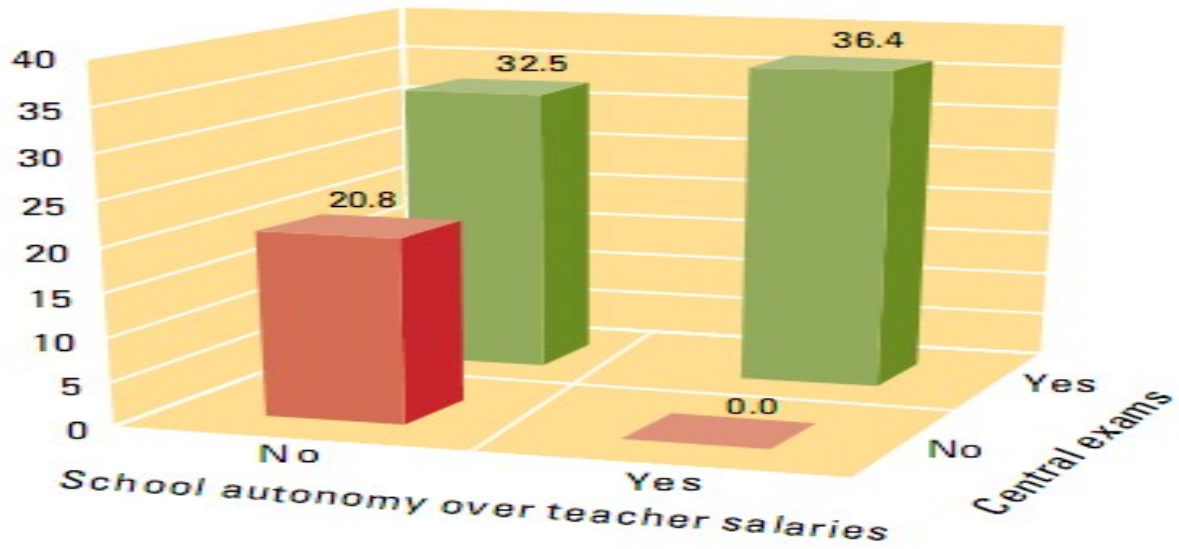

Figure 9. The Impact of Interaction between Autonomy and Testing towards Learners (Resource: Wößmann, 2005a) 
There are three important policies to encourage the improvement of the overall quality performance in school namely (1) accurate assessment system to measure the learners' performance; (2) local autonomy which allows schools to suit their choices in education; (3) the choices and competitions to promote high motivation.

The success of education relies on the indicators set out by the educational institutions or units. Each indicator has different function in regard to the audience in different contexts. These are to be claimed that there are nine basic indicators of education: (1) demography of society, learners and family, (2) tuition fee, (3) preparation and support of early childhood education learning program, (4) school leadership, (5) school climate, (6) relationship between school and society, (7) teaching and learning environment, (8) perception on satisfaction of public, parents, learners ,and teachers, (9) learners' learning achievement. In relation to the indicators, Theodore W. Frick (2012) set out four dimensions of education quality: (1) content, (2) context, (3) process and, (4) quality outcomes. The quality outcomes are greatly influenced by the dimensions of environment, content, process, and learner as well as teacher as a learner.

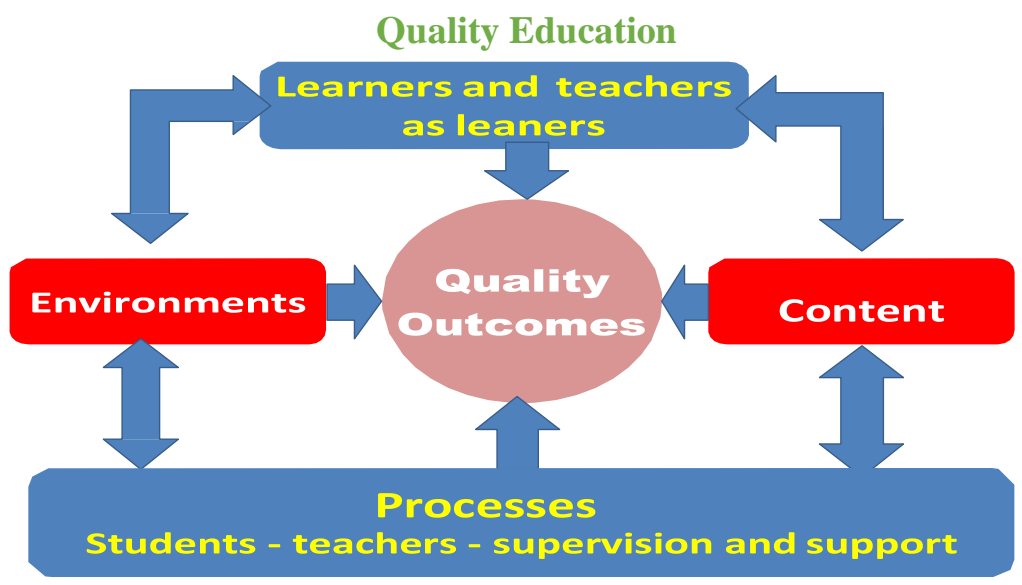

Figure 10. Quality Education (Source: Theodore W. Frick, 2012)

The diagram above is adopted from EFA Global Monitoring Report 2005 funded by UNESCO. There are five dimensions of education quality in relation to basic education quality.

\section{a. Learner characteristics}

Production function theory suggests that the learners' characteristics commonly refers to the inputs or raw inputs which has a wide variety of backgrounds i.e., such as aptitude, perseverance, school readiness, learners' prior knowledge, and barriers to learning, especially for learners with special needs.

\section{b. Enabling inputs}

Education quality is influenced by two inputs, i.e. human resources and physical infrastructure. Human resources include teachers, principals, supervisors, and other teaching staffs whom influences the learning outcomes quality. Teaching and learning processes may fail to be carried out with safety and convenience unless 
the physical infrastructure or facilities, such as school building, classroom, learning materials, media and learning aids, library, laboratory, cafeteria textbooks and curriculum.

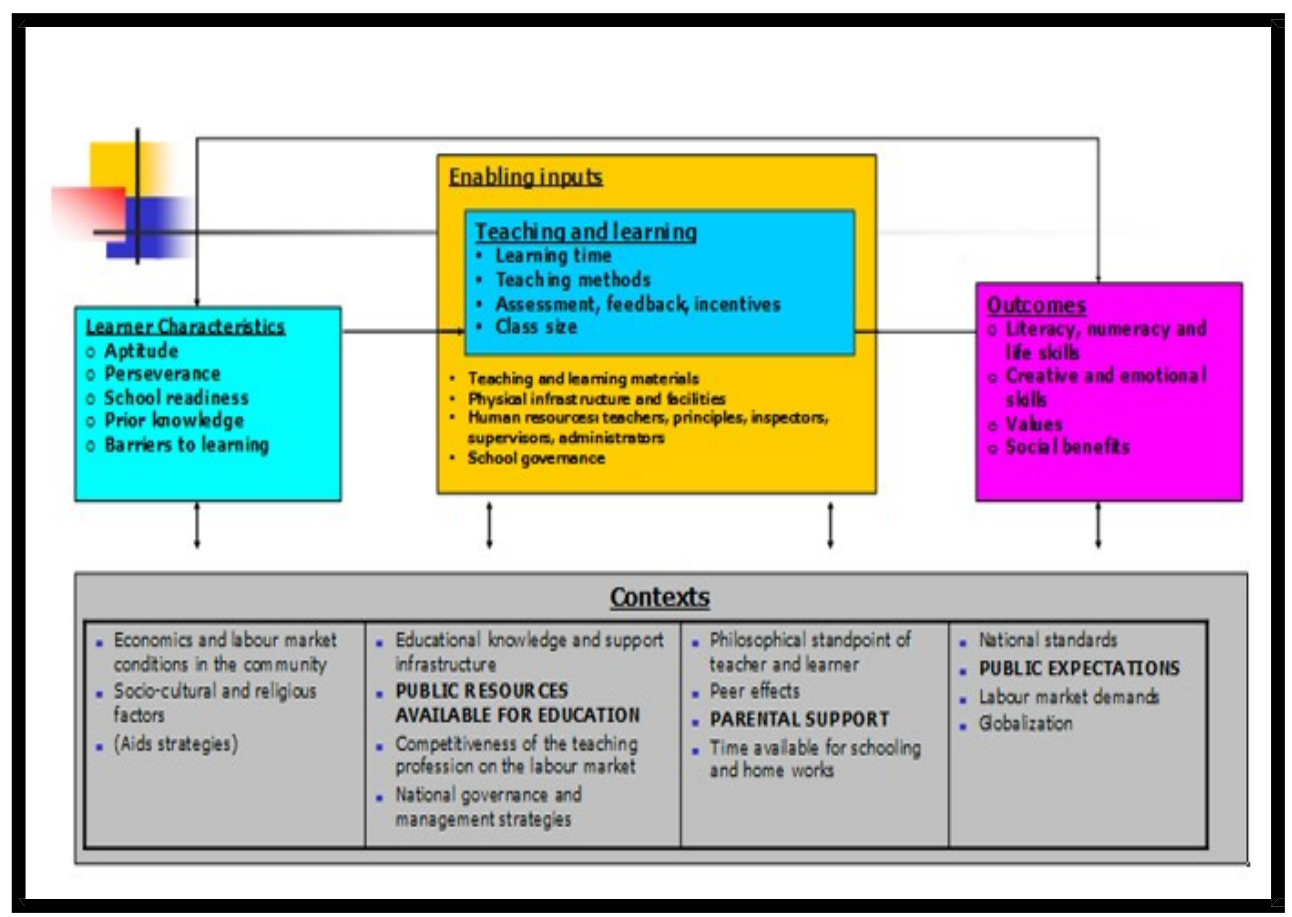

Figure 11. Five Dimensions of Education Quality Source: EFA Global Monitoring Report 2005, UNESCO, page. 36

\section{c. Teaching and learning}

The third dimension derives from what is known as the black box of educational problem. There are three main educational components, i.e. learners, teachers, curriculum and assessment. Therefore, the quality of teaching and learning process influences the education quality. The effectiveness of teaching and learning process relies on: (1) the learning period, (2) the appropriate use of teaching method, (3) the assessment of result and process, (4) the feedback for revision and improvement, (5) the rewards for learners and teachers, (6) the ratio of learners and teachers in an institution. In addition to this, Suparlan (2006) argues that prosperity becomes the center of problem in teaching and learning process.

\section{d. Outcomes}

Education will come to a success if learning outcomes fully meet the needs of society and environment. The world of business and industry expects to have secondary-level graduates ready to work. Within this viewpoint, the vocational education is developed to meet the expectation. However, the expectation does not efface the significant support for early childhood and primary education. All levels of education should generate graduates with reading and writing literacy, numeracy and life skills. In addition to these, the graduates should also be equipped with emotional and social intelligences and other values which are needed for competition 
amongst individuals, groups or companies, and nations (Daniel Goleman, 2002: 49, cited in Suparlan, 2004).

\section{e. Contexts or environments}

The four dimensions above influence the contexts or environments in regard to the aspects of science, social, economy, and culture, such as (1) the eeconomics and labor market conditions in the community (human capital), (2) the socio-cultural and religious factors, (3) the educational knowledge and infrastructure.

Public resources available for education includes (1) competitiveness in teaching profession on the labor market, (2) governance and management strategies, (3) pphilosophical standpoint of teacher and learner and, (4) peer effects. Parental support includes time available for schooling and home works and, national standards. Public expectations includes (1) labor market demand, (2) globalization.

\section{CONCLUSION}

The improvement of PPR percentage of JHS, requires the involvement of individuals and groups of society. This design is based on the following assumption: (1) there is no difference between people living in rural and urban areas to utilize educational services and opportunities, (2) there is no difference between male and female to utilize educational services and opportunities, (3) the financial expenditure of learners' families do not play any role in improving the learning achievements, (4) there is no difference between individuals' and families' abilities to obtain learning opportunities, (5) no difference in service between public and private schools is found.

It is important to improve quality and relevance of basic education as well as efficiency of educational resources utilization management in educational institution as this will generate graduates with basic competence of life skills to pursue highlevel education, including those who live in the less developed, border, isolated and remote areas.

The international benchmark positions Indonesian children having lower competence in reading, mathematics, and science literacy than those of other developed and developing countries. Otherwise, Indonesian children competence have better some other countries even though it has low GNI and GDP per capita. In order to rectify this, the educational program has to be well-supported with the achievement analysis of reading, mathematics, and science literacy that remain low in basic education level. This can be conducted by participating in international studies. This is owing to the fact that education quality has a significant influence towards economic growth. 


\section{REFERENCES}

Barro, Robert J. (2001). “Human Capital and Growth”. American Economic Review 91 (2): 12-17.

Bishop, John H. (1997). "The Effect of National Standards and Curriculum-Based Examinations on Achievement”. American Economic Review 87 (2): 26064.

Carnoy, Martin, and Susanna Loeb. (2002). "Does External Accountability Affect Student Outcomes? A Cross-State Analysis”. Educational Evaluation and Policy Analysis 24 (4): 305-31.

Coulombe, Serge, Jean-Francois Tremblay, and Sylvie Marchand. (2004). Literacy Scores, Human Capital and Growth across Fourteen OECD Countries. Ottawa: Statistics Canada

Delors, Jacques. (1996). “Learning”: The Treasure within, report to UNESCO of the International Commission on education for the twenty-first century. Paris: UNESCO Publishing.

De Gregorio, Jose, and Jong-Wha Lee. (2002). “Education and Income Inequality: New Evidence from Cross- Country Data”. Review of Income and Wealth 48 (3): 395-416.

Frick, T. W. (2012). Dimentions of Educational Quality. Department of Instructional Systema Technology, School of Education, Indiana University Bloomington. USA.

Galiani, Sebastian, and Ernesto Schargrodsky. (2002). "Evaluating the Impact of School Decentralization on Educational Quality”. Economia 2 (2): 275314.

Hanushek, Eric A. and Kimko. (1994). Making Schools Work: Improving Kinerjance and Controlling Costs. Washington, D.C.: The Brookings Institution.

Hanushek, Eric A., and Ludger Wößmann. (2007). “The Role of Education Quality in Economic Growth”. Policy Research Working Paper 4122, World Bank, Washington, D.C.

Hanushek, Eric A., and Ludger Wößmann. (2007). Educational Quality and Economic Growth. World Bank, Washington, D.C.

Jacob, Brian A. (2005). “Accountability, Incentives and Behavior: The Impact of High-Stakes Testing in the Chicago Public Schools”. Journal of Public Economics 89 (5-6): 761-96. 
Jurges, Hendrik, Kerstin Schneider, and Felix Buchel. (2005). “The Effect of Central Exit Examinations on Student Achievement: Quasi-Experimental Evidence from TIMSS Germany”. Journal of the European Economic Association 3 (5): 1134-55.

Kemdiknas. (2010). Mencapai Pendidikan Dasar untuk Semua. Laporan pembangunan pencapaian tujuan pembangunan meillenium Indonesia, PDF Jakarta.

Lockheed, Marlaine E., and Eric A. Hanushek. (1988). “Improving Educational Efficiency in Developing Countries: What Do We Know?” Compare 18, no. 1: 21-38.

OECD (Organization for Economic Co-operation and Development). (2004). Learning for Tomorrow's World: First Results from PISA 2003. Paris: OECD.

Scheerens, J. \& Maria Hendriks. Benchmarking the Qualiy of Education. Report on the Network C primary school survey. Paris: OECD.

Soegiarto. (2012). Building Nation Means Building Schools. Prenting paper for National Seminar, Balitbang, MOEC.

Suparlan. (2007). Dimensi Mutu Pendidikan. Situs web Suparlan, PDF. Jakarta.

Suryadi, Ace. (2011). Educational Outlook, Balitbang Kemdikbud. Draft Laporan, Jakarta.

Temple, Jonathan. (2001). "Growth Effects of Education and Social Capital in the OECD Countries”. OECD Economic Studies 33: 57-101.

Udin S. Saud dan Mulyani Sumantri. (2010). Pendidikan Dasar dan Menengah. Makalah, dokumen PDF.

UNICEF. (2000). Defining Quality in Education. Working Paper Eeries, Education Section Program Division, UNICEF, New York, USA.

UNESCO. (2008). Qualitative Indicators. Capacity Building Workshop on Monitoring and Evaluating, Progress in Education in the Pacific. Nadi, FIJI, AIMS, Bangkok.

World Bank. (2004). World Development Report 2004: Making Services Work for Poor People. Washington, D.C.: World Bank.

World Bank Independent Evaluation Group. (2006). From Schooling Access to Learning Outcomes: An Unfinished Agenda. Washington, D.C.: World Bank. 
Wößmann, Ludger. (2001). “Why Students in Some Countries Do Better”. Education Matters 1 (2): 67-74.

. (2005a). "The Effect Heterogeneity of Central Exams: Evidence from TIMSS, TIMSS-Repeat and PISA”. Education Economics 13 (2): 143-69. 